\title{
Ver, tocar, creer: travesías de la mirada religiosa en las estampitas devocionales ${ }^{1}$
}

\author{
To Touch, to See and to Believe: \\ Haptic Visuality Trails through Holy Cards ${ }^{2}$
}

\author{
Lily Jiménez Osorio \\ Centro de Estudios Judaicos, Universidad de Chile \\ ljimenezo@uchile.cl
}

\section{Resumen}

El objetivo de este artículo es explorar los mecanismos de la visualidad háptica aplicada a imágenes religiosas de reproducción masiva. Para ello, se ha trabajado con una muestra de estampas devocionales católicas perteneciente al Museo Histórico Nacional, las que corresponden a imágenes del Sagrado Corazón en sus distintas variantes. Sostengo que el carácter háptico de las imágenes es fundamental para la mirada religiosa y las formas de la creencia, evidenciando los mecanismos de persuasión que estas imágenes comportan, así como sus implicaciones táctiles, visuales y corporales.

Palabras clave: Mirada religiosa, visualidad háptica, estampitas católicas, Sagrado Corazón.

\begin{abstract}
The main purpose of this paper is to explore the procedures and functioning of haptic visuality through images that are mass produced. To achieve that, I will describe and analyze a repertory of Catholic holy cards and devotional stamps that belongs to the National History Museum (Chile), focusing on those featuring The Sacred Heart in some of its variations. I affirm that the haptic character of these images is paramount for the sacred gaze and belief, highlighting those persuasion tactics that these images cast, alike their visual, tactile, and bodily implications.
\end{abstract}

Keywords: Sacred gaze, haptic visuality, Catholic holy cards, Sacred Heart.

1 Este artículo forma parte de la investigación de tesis doctoral titulada "La emergencia de una cultura visual religiosa: apropiación y recorridos devocionales de estampitas católicas a fines del siglo XIX y principios del xx a partir de la colección del Archivo Histórico Nacional", la que está siendo realizada en el programa de Doctorado en Estudios Americanos, mención Pensamiento y Cultura, del Instituto de Estudios Avanzados de la Universidad de Santiago.

2 Una primera aproximación a este tema lo realicé junto al historiador del Museo Histórico Nacional Hugo Rueda, con quien nos adjudicamos un Fondo de Apoyo a la Investigación Patrimonial (FAIP-DIBAM) el año 2015. Con ese fondo pudimos documentar un volumen de 128 piezas, así como realizar los primeros acercamientos teóricos y descriptivos al conjunto. 


\section{Ver/tocar para creer}

En el pasaje bíblico conocido como la incredulidad de Tomás se describe una de las bases de la creencia del cristianismo que se ha utilizado como modelo ejemplar. En dicha escena, Cristo resucitado se aparece a algunos de los apóstoles, quienes le cuentan luego a Tomás sobre el acontecimiento, a lo que él responde: "Si no veo en sus manos la señal de los clavos y no meto mi dedo en el agujero de los clavos y no meto mi mano en su costado, no creeré" (Juan 20:25, el énfasis es mío). ${ }^{3}$ Ocho días después, Jesús se aparece nuevamente a todos los discípulos y se dirige especialmente a Tomás, diciendo “'Acerca aquí tu dedo y mira mis manos; trae tu mano y métela en mi costado, y no seas incrédulo sino creyente' [...] 'Porque me has visto has creído. Dichosos los que no han visto y han creído"' (Juan 20: 27-29, el énfasis es mío). Tradicionalmente esta escena se utiliza para enfatizar la sentencia que cierra el episodio: la creencia debe participar del misterio, debe basarse en aquello que no se ve, debe afirmarse ciegamente. Creer se entiende como una forma de afirmar un discurso, de participar en él (como diría Michel de Certeau). Sin embargo, este pasaje nos enfrenta a otro problema: la aparición corporal, la presencia absoluta del resucitado (dogma fundamental de la Iglesia), donde la creencia es absoluta. En cuanto revelación física se hace presente y fulmina las dudas.

Existe una peligrosidad de contagio entre ver y tocar que no se puede soslayar, como si la primera condujera a la segunda indefectiblemente. ${ }^{4}$ Se tiende a usar las metáforas de la mirada como expresiones de alejamiento y situación: se ve desde la distancia, se observa sin participar de lo observado, se objetiva mediante la mirada. Una serie de dispositivos visuales apuntan a ello: la perspectiva italiana, por ejemplo, que se vindica como una representación que sitúa necesariamente al observador fuera del plano y como criterio de verdad (Mitchell), o los mecanismos de representación fotográfica que nos interponen un dispositivo mecánico entre el objeto y el observador. Estas modalidades de la visión operan como formas puramente ópticas. No obstante, la mirada puede ser entendida también en un sentido corporalizado que implica formas de tocar, y cuyo toque conduce a la confirmación de la creencia, como en el relato de Tomás, quien llega al punto de penetrar en la herida del cuerpo de Cristo. La mirada religiosa es una mirada cargada de ese contacto, de búsqueda de cercanía, y parte de lo que algunos autores han llamado una experiencia háptica de la visualidad, donde "la mirada procede como el tacto experimentando en el mismo lugar la presencia de la forma y el fondo" (Deleuze 71). Podría incluso

3 Utilizo la Biblia de Jerusalén por ser una traducción basada en lineamientos teológicos dentro del catolicismo romano, que es la rama del cristianismo que me interesa trabajar en este ensayo. Otras traducciones útiles pueden ser la de Reina-Valera, conocida por su literalidad (y utilizada principalmente por evangélicos y ortodoxos) y la de Nácar-Colunga (que fue la traducción más popular después del Concilio Vaticano II).

4 No puedo dejar de mencionar la hipótesis de David Freedberg relativa a la iconoclasia, en la que sostiene que las imágenes son peligrosas por su sensualidad: la imagen apela directamente al cuerpo, por ello son atacadas (423-474). 
sugerirse que la frase que hace famoso ese relato no debería ser "ver para creer", sino que "tocar para creer".

Muchos estudios sobre asuntos religiosos tienden a girar exclusivamente en las formas discursivas y doctrinarias de las creencias, así como en las formas institucionales, su organización o su declive. Con cada vez más frecuencia, diversos autores están poniendo el acento en las formas performáticas, en los objetos, en las corporalidades que constituyen la creencia. ${ }^{5}$ Parto de la premisa de que las formas de creer son necesariamente corporales, por lo tanto, están conectadas con las percepciones y las sensaciones. El cuerpo es tanto mi lugar de enunciación como lugar epistemológico para investigar.

En este ensayo quisiera volver al ejercicio de mirar algunas imágenes observando su afectación, reflexionando sobre las formas de ver y tocar, así como las distintas implicancias que tiene su tamaño, uso y circulación. Las imágenes que he escogido corresponden a "estampitas" datadas a comienzos del siglo xx. Estas imágenes son de pequeño formato y fueron producidas para la devoción privada. Por sus dimensiones son objetos que tienden a ser portables, a mantenerse cerca del cuerpo, puesto que muchas veces se usan para orar o bien como amuletos. Esta relación de intimidad hace de estos objetos un caso ilustrativo de la experiencia visual háptica. En este ensayo busco dilucidar aquellos elementos que conforman una cultura visual religiosa específica, por ello me apoyo en los estudios de la visualidad, incorporando algunas observaciones realizadas por los filósofos Jacques Derrida, Jean Luc Nancy y Gilles Deleuze en torno al tacto y la visión.

He tomado algunas decisiones estratégicas que me parece necesario evidenciar. Las estampitas, por cuanto objetos de reproducción masiva, son materiales difíciles de reunir en un corpus particular, por ello he decidido trabajar con un grupo que custodia el Museo Histórico Nacional. Su ingreso al museo permite observarlas como un conjunto, el que no necesariamente obedece a criterios unificados: algunas ingresaron en conjunto con otros objetos (fotografías, textiles, imágenes), otras fueron donadas por particulares bajo motivaciones que no podemos rastrear, ya que los registros de donación no consignan dichos motivos. Un último grupo de estas estampitas fue donado a propósito de una exposición sobre imágenes devocionales, ${ }^{6}$ y en dicha ocasión se encontraron donaciones que no habían sido registradas. Dentro

5 Desde los estudios religiosos en la academia anglosajona han cobrado notoriedad los "estudios de religión material", que congregan a historiadores del arte, antropólogos, arqueólogos e historiadores, quienes han cuestionado precisamente las formas tradicionales de entender la religiosidad sin atender las formas materiales (Morgan, Religion and Material $y$ The Embodied Eye; King; Droogan; McDannell; Meyer et al.). Este giro hacia los estudios de lo material y la corporalidad en la religiosidad también ha sido abordado desde Latinoamérica, donde se podría destacar el trabajo de Renée De la Torre junto a Eloísa Martín, quienes dan cuenta de cómo la reflexión se ha ido desplazando desde los problemas del catolicismo, la secularización, la religiosidad popular y el problema del sincretismo y el mestizaje.

6 Durante el año 2016, en la sala Gobernadores para exposiciones temporales se organizó "Formas para recordar: objetos e imágenes de devoción", que reunió estampitas y objetos devocionales en torno a los hitos sacramentales católicos. En dicha ocasión, se realizó una investigación con entrevistas para contextualizar los objetos, además de aceptar donaciones de los entrevistados. Ver Báez et al. 
de este acervo destacaré cuatro imágenes que representan sagrados corazones, las que he seleccionado porque la iconografía de los sagrados corazones (en sus distintas variantes) es una de las pocas recurrentes en el repertorio. Además, las imágenes escogidas corresponden a una misma tipología orientada a la práctica de la oración, por lo que su uso está muchas veces estipulado en la imagen misma. ${ }^{7}$

\section{Tocar con los ojos}

Las imágenes operan en modalidades que van desde sus características intrínsecas (propias de la imagen, tales como efectos visuales, composición, significado visual), sus condiciones de producción (técnicas, género o formato, público específico) y sus efectos sobre una audiencia en particular (circulación, relación con otros documentos, interpretaciones). Para concentrarnos en las formas de visualidad, en este ensayo me enfocaré en cómo los elementos que podemos observar dentro de la imagen nos hablan de sus usos, circulaciones y efectos sobre el usuario. En particular, por tratarse de imágenes religiosas, comportan características específicas en su uso e interpretación.

En general, las imágenes se tienden a pensar como una separación desde la representación: toman el lugar de una ausencia por cuanto vuelven a hacer presente un referente. Se las ve pero no se tocan. Podríamos denominar un régimen visual como puramente óptico a aquel que busca crear espacios de disociación del observador con lo observado: se trata de imágenes que generan la ilusión de un espacio otro, la continuidad visual de un espacio en el que no se puede ingresar. El espacio puramente óptico, sostiene Deleuze, es un espacio que ha subordinado el resto de los sentidos, especialmente el tacto. En esa subordinación se jerarquizaron también los sentidos dignos de ser formas de conocimiento: ver desde la distancia es una forma de objetivar, de no involucrarse con el objeto de estudio, mientras que los otros sentidos implican contaminación con el objeto. Esta marca es también la de la modernidad. Las imágenes resultantes de esta epistemología moderna marcan una distancia, como diría Nancy, no se las puede tocar, porque ese toque las desvirtúa en su apropiación. Sin embargo,

¿qué es la vista, sin duda, un tocar diferido? Pero ¿qué es un tocar diferido sino un tocar que aguza o que destila sin reserva, hasta un exceso necesario el punto, la punta y el instante por el que el toque se separa de lo que toca en el momento mismo que lo toca? Sin esa separación, sin ese retroceso o esa retirada, el toque no sería ya lo que es y no haría lo que hace (Nancy 79-80).

7 En la muestra que analizaré no he incluido tarjetas conmemorativas de bautismos, defunciones u ordenaciones (a pesar de que muchas de ellas ilustran el mismo tema iconográfico), ya que la función y circulación es distinta. Las tarjetas son hechas para recordar, además son objetos estrictamente privados, obedecen a lógicas familiares, en ellas se consigna información íntima (nombre de los bautizados, fecha, padres, padrinos) y son objetos que transitan en ámbitos más bien domésticos (Rueda 2016). 
Observar y contemplar no son las únicas maneras de relacionarse con las imágenes. Una diferencia que podríamos establecer entre las imágenes religiosas y aquellas que cumplen otras funciones es el tipo de práctica con la que se vincula el observador. Las imágenes religiosas están rodeadas de operaciones que las enredan en medio de prácticas afectivas: a ellas se les canta (como los cantores a lo divino), o se les baila, muchas de ellas son tocadas o besadas (como los íconos ortodoxos), se les quema incienso, se prenden velas frente a ellas. A otras imágenes (como las de bulto) se les lleva en andas, se les acaricia o se las mece (como a las figuras del Niño Dios), se habla y se convive con ellas. Todas estas acciones dan sentido a determinadas comunidades, toda vez que vehiculizan formas de creer, formas de ver.

La mirada está constituida por configuraciones que implican disposiciones corporales engarzando "la proyección de las convenciones que habilitan ciertas posibilidades de significado, ciertas formas de experiencia y ciertas relaciones entre participantes" (Morgan, The Sacred Gaze 4, la traducción es mía). En este sentido, hablar del concepto de mirada implica designar un campo visual que vincula al observador, lo visto, las convenciones y regímenes de la mirada (qué es lo que se permite ver y representar) así como los contextos históricos, los mecanismos, dispositivos y medios que hacen posible esas formas de ver. Articular dichos elementos entregaría luces para entender el funcionamiento de una cultura visual específica.

Una forma particular de visualidad es lo que David Morgan llama "la mirada sagrada", la que se caracteriza por mediar entre formas visibles e invisibles, toda vez que activa la sacralidad en el uso que proyecta sobre las imágenes:

Lo que hace "religiosa" a una imagen no es simplemente su contenido o las intenciones de la persona que la ha creado, sino el uso de la imagen, así como el contexto de su despliegue e interpretación. En cada caso, la imagen es mejor entendida como parte integral de una práctica visual, es decir, una mediación visual de relaciones en el interior de un grupo humano particular, y las fuerzas que ayudan a organizar su mundo (Morgan, The Sacred Gaze 55, la traducción es mía).

En este registro, la visualidad háptica es crucial, puesto que el rol del observador está "entrelazado con lo que está siendo observado, derribando las barreras entre el observador y el objeto" (Nooter Roberts 81, la traducción es mía). Las imágenes afectan y, a su vez, conmueven: ante ellas se llora, se estremece o se regocija el observador (Elkins). Dicha afectación, como sostiene Alejandra Castillo, es una forma de toque que devuelve la imagen. Afirma la autora: "Este poder de afectación permite descorrer y explicitar los marcos de clausura de la imagen en una interpretación, en una sola descripción. Siempre hay más de una imagen en la imagen, una que subvierte, altera, el registro de lo visible" (61). Pienso que parte de esa alteración es una dualidad que dice relación con las formas en que el cuerpo se relaciona con la imagen, con las formas de crear contactos, cercanías o espacios de alejamiento. En 
el caso de la imagen religiosa, sospecho que está relacionada con la transitividad o turbiedad de su representación.

Las estampitas devuelven la mirada, entregan una forma de compañía que se podría interpretar como un valor de proximidad. Como señala Derrida, comentando la obra de Deleuze, dicho valor es clave, puesto que ese "vector de la presencia cercana determina en última instancia el concepto y el vocablo 'háptico', porque lo háptico abarca virtualmente todos los sentidos donde sea que se apropien de una proximidad" (185). Las estampitas religiosas actúan de manera cercana a las reliquias (como sacralidad fundante) en virtud de ese valor, el que incrementa su sentido sagrado.

La mirada, como sentido privilegiado por la modernidad para la construcción del conocimiento, se vuelve a corporizar en sus formas religiosas: apela al contacto y al toque desde diversas estrategias visuales y materiales, las que acompañan desde la mirada. Las estampitas son objetos que canalizan un sentido pastoral católico que se hace imperioso a principios del siglo $\mathrm{xx}$, debido en parte a la presión ejercida por otras denominaciones cristianas, así como las supuestas amenazas que predicaban las teorías de la secularización. Por ello, sus estrategias visuales son también estrategias pedagógicas, lo que se hace particularmente evidente en el caso de la devoción al Sagrado Corazón.

Es necesario constatar que cuando hablo de "estampitas" me estoy refiriendo a un universo amplio de objetos impresos. Las estampitas abarcan tipologías heterogéneas: desde invitaciones, recuerdos de sacramentos (primeras comuniones, bautismos, ordenaciones), hasta impresiones de oraciones, imágenes de santos con sus historias y jaculatorias, o simplemente imágenes sin referencias escritas. Las técnicas de reproducción son también variadas, algunas corresponden a técnicas fotográficas, litografías o grabados, decorados con troquelados y diversos tipos de papel. Lo que unifica a estos objetos es su uso: objetos para recordar o para rezar, con los que los devotos mantienen una independencia en su relación con (o instalación de) la sacralidad. ${ }^{8}$

Históricamente, la devoción al Sagrado Corazón de Jesús tiene su origen a finales de la Edad Media con la figura de Santa Gertrudis. ${ }^{9}$ Sin embargo, alcanza notoriedad con la monja visitacionista Margarita María de Alacoque (1647-1690). Las visiones de esta monja plantearon problemas teológicos fundamentales a lo largo del siglo XVII por su marcado carácter erótico y corporal, aunque sus visiones fueron intervenidas para

8 Si bien el estudio de estas imágenes podría considerarlas como una forma de religiosidad popular, creo que la transversalidad de su uso, así como su fomento eclesial, desbordan dicha categoría. Me parece relevante distinguirlas de otros objetos considerados (por los devotos) como sagrados por sí mismos o que emiten algún tipo de sacralidad, como podrían ser las reliquias o las hostias consagradas. En cambio, estas imágenes son utilizadas para generar un recuerdo de un hito en la biografía de un católico, o bien para abrir un espacio de sacralidad. Estas imágenes podrían considerarse como objetos de una sacralidad instituyente en el sentido que Eloísa Martín y María de Lourdes Jacobo dan al concepto.

9 Es interesante destacar que muchas iconografías anteriores al siglo xix siguen destacando la imagen de Santa Gertrudis con el sagrado corazón de Jesús, como por ejemplo la pintura que se custodia en el Museo Nacional de Bellas Artes (http://www.surdoc.cl/registro/2-118 [Consultado 29 de junio de 2018]). 
elevar el corazón como símbolo de amor y sumisión cristiana. Durante el siglo XIX, el Sagrado Corazón de Jesús se acepta como una de las devociones más importantes del catolicismo, ${ }^{10}$ siendo reconocida como el emblema de la salvación por vía del amor divino. Como ha sostenido David Morgan, esta devoción marcó cambios en las prácticas rituales, transformando un régimen devocional basado en el sufrimiento (la imagen tridentina) a uno basado en la comunidad y la simpatía (The Sacred Heart 2012). Este cambio se refleja en los distintos juegos que tiene la mirada religiosa dentro de las iconografías: de una mirada empática que buscaba identificarse con el objeto, replicando las acciones representadas, a una mirada que es devuelta por la imagen. Esa mirada que retorna no tiene un carácter vigilante sino amoroso, y por ello trae el corazón mismo por delante desalojado de su cuerpo, como un símbolo de acogida, ternura y amor.

Las estampitas son además imágenes relativamente anónimas. A diferencia de una obra de arte que está firmada, no tienen pretensiones de originalidad, autenticidad o de unicidad. Solo algunas de ellas contienen información sobre las casas de impresión que las producen. No sabemos quiénes las diseñaron, sino quiénes imprimieron algunas. La reproducción es su origen y sentido, están pensadas para migrar, ser exportadas, copiadas, reproducidas donde son acogidas. La reproductibilidad modela sus lenguajes visuales, creando claves visuales que simplifican los procesos de reproducción, volviéndose un formato muy popular y actual. Son objetos multidimensionales en su diseño (forma, tamaño, diagramación, composición), y a partir de dicha multiplicidad tramaré los recorridos del tocar, el ver y el creer, los que a veces pueden trazarse a través del formato y sus texturas, otras veces pueden reconocerse en la iconografía, y en otras ocasiones, se puede aprehender a través de sus escrituras.

\section{Travesías de la mirada háptica}

En las imágenes que examinaré pretendo dar cuenta de un recorrido de la visualidad háptica que opera en distintas capas. Desde una imagen sin palabras, donde no hay nada escrito pero todo sugerido para tocar, a otras donde la circularidad de la mirada se suspende en la imagen para proyectarse al espectador. Destacaré elementos de lo háptico que Deleuze analiza en "obras de arte", donde observa en el uso de los colores, la superficie creada por las imágenes y la capacidad de expresar conexiones con "la actividad orgánica del hombre" (73).

Quisiera empezar por una fotografía de contenido religioso, la que es casi única en su tipo dentro de este conjunto [Figura 1]. ${ }^{11}$ No contiene ninguna escritura que

10 Cabe mencionar que el Papa León xiII consagra la humanidad al sagrado corazón en el año 1899 a través de su encíclica "Anuum Sacrum".

11 Para ver los detalles de la documentación de esta imagen, recomiendo visitar su registro en el catálogo suRdoc de la DiвAM. Ver: http://www.surdoc.cl/registro/3-41635 (Consultado 29 de junio de 2018). Otras tarjetas contienen impresiones fotográficas, desde tarjetas de bautismos a invitaciones a matrimonios. 
nos permita situarla en algún hito particular. Esta estampita representa dos sagrados corazones fotografiados a comienzos del siglo xx. Se pueden reconocer porque el Sagrado Corazón de Jesús tiene espinas y un crucifijo en su parte superior, mientras que el de María está bordeado de rosas y atravesado por una espada, simbolizando el dolor por la muerte de su hijo. ${ }^{12}$ Además, el corazón de la Virgen está coronado por tres lirios que simbolizan su pureza y castidad. Probablemente dichos objetos fueron confeccionados (o tallados o moldeados en yeso) para ser fotografiados, y sobre la fotografía se ha realizado una intervención para completar los atributos del corazón de María.

Esta imagen, producida en gelatina sobre papel, parece comportar todos los elementos de una fotografía clásica con procesos de montaje. Ello destaca las posibles pretensiones de realidad de la imagen: son objetos reales que podríamos alcanzar como Tomás entrando en la herida de Cristo. No se trata de una aparición celestial, sino de dos objetos que nada tienen de inerte, muy por el contrario, devuelven una mirada compasiva, pletórica de texturas que llaman a ser acariciadas.

Si miramos detenidamente esta estampita, diversos elementos nos llaman a tocarla. No es solo la mirada como un toque diferido lo que se proyecta sobre la imagen, sino también la posibilidad de ingresar, como a través de una ventana, a esos objetos que aparecen de manera muy táctil debido al detalle de sus relieves. La falta de profundidad en la perspectiva y la iluminación neutra colaboran con esa sensación, no distinguiéndose con claridad un fondo de los objetos o un lugar donde situarlos.

Los corazones están contenidos en un óvalo ${ }^{13}$ cuyos límites se encuentran difuminados, lo que entrega una suerte de suspensión a los objetos, como un espacio diferente que se desborda hacia el observador, contaminando el espacio de su influencia. Esta imagen permite un acceso a través de la sensación: tocarla para sentir la rugosidad de las llamas, la sinuosidad de los corazones, la aspereza de sus espinas. No pasa lo mismo con la espada, cuyo filo se pierde en su transparencia y falta de contraste.

Ahora bien, cabría preguntarnos por las motivaciones para realizar este tipo de montaje en la elaboración de esta imagen. Como he señalado, es una imagen producida bajo diferentes mecanismos: una primera impresión sobre una película fotosensible, seguida de una impresión en papel intervenida con dibujo, y una última posible recaptura en una fotografía que unifica el montaje. Dicho proceso apela a presentar una presencia terrenal: los corazones aparecen como objetos opacos, no hay ocultamiento, sino presencia absoluta.

12 En el episodio bíblico de la presentación del niño Jesús en el templo, Simeón se dirige a la Virgen, vaticinando el sufrimiento de la pasión. Entonces se narra: "y una espada atravesará tu alma para que se descubran los pensamientos de muchos corazones" (Lucas 2:35).

13 Esta puede ser una pista para fechar el objeto. Probablemente corresponde a una fotografía obtenida con una cámara Brownie de Kodak, lo que la sitúa en un tiempo: 1900-1915 aproximadamente. 


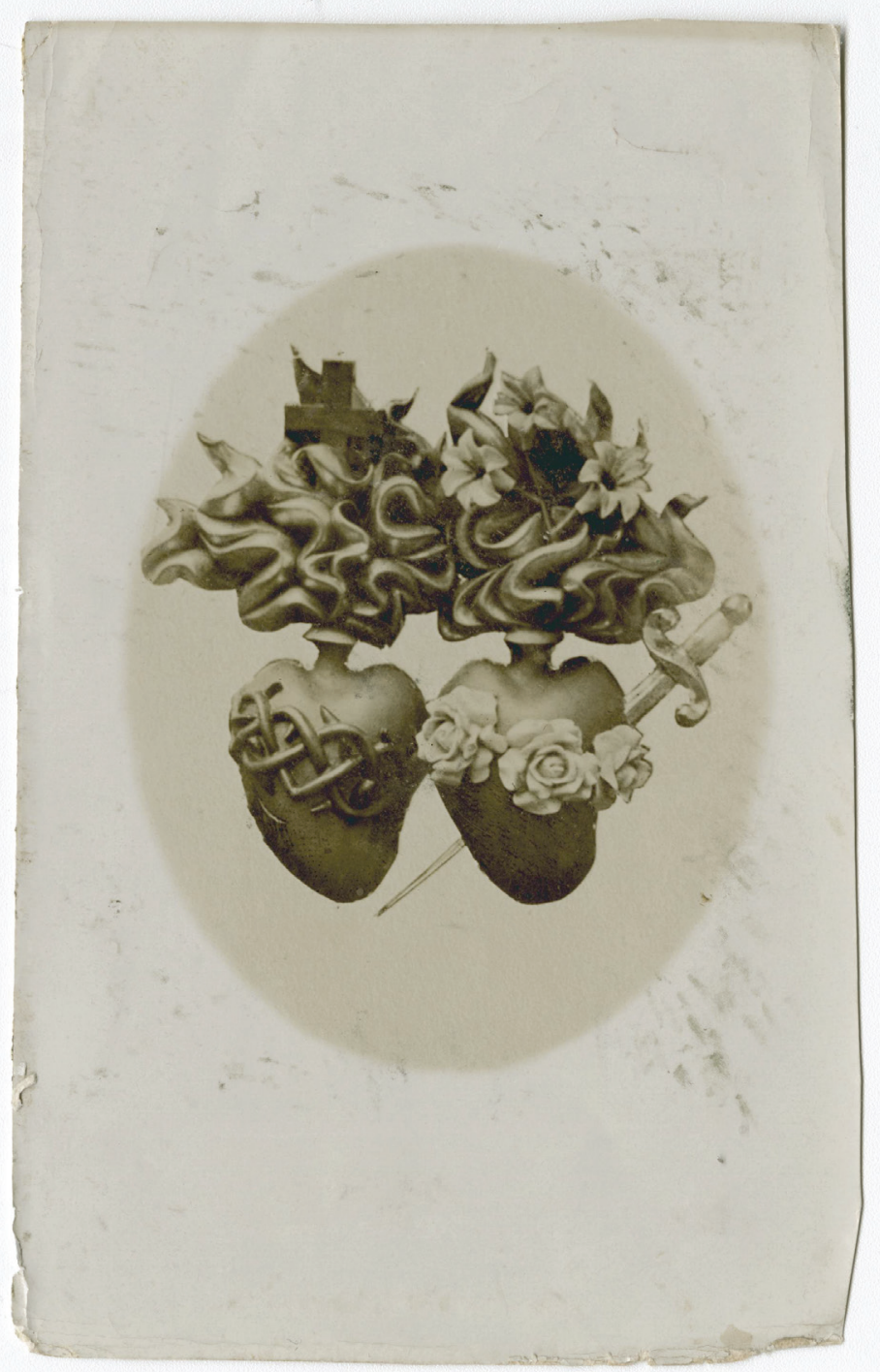

FIGURA 1

Estampa religiosa con la impresión de dos sagrados corazones. Fotografía de gelatina sobre papel, $7.5 \mathrm{~cm} \times 11.85 \mathrm{~cm}$, ca. 1900 . Colección Libros y Documentos, Museo Histórico Nacional. 


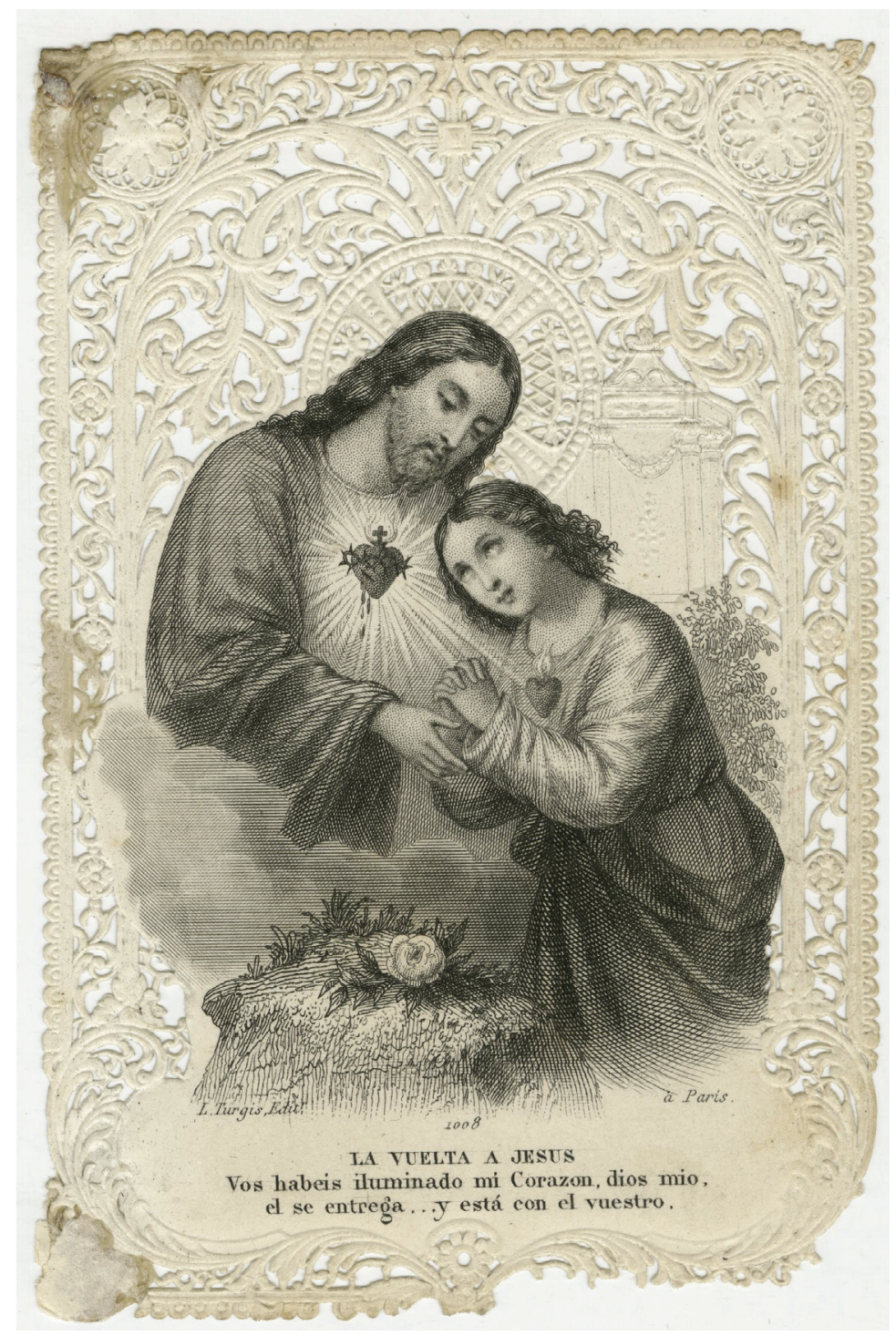

FIGURA 2

Estampa religiosa con motivo de Sagrado Corazón de Jesús. Troquelado, grabado e impresión sobre papel, $7.5 \mathrm{~cm} \times 11.8 \mathrm{~cm}$, s. XIx. Colección Libros y Documentos, Museo Histórico Nacional. 
La segunda estampita que quisiera destacar es una tarjeta de oración [Figura 2]:14 por su parte anterior presenta un grabado con la imagen del Sagrado Corazón de Jesús junto a un devoto con sus manos en gesto de oración, mientras que por su cara posterior se encuentra una plegaria. Es importante señalar que muchas de estas estampas son realizadas con licencia eclesiástica, por lo que las oraciones están censuradas por la curia, y muchas son importadas desde Francia, que en el siglo xix desarrolla una estética particular en los talleres de Saint Sulpice. Ello resalta su carácter institucional y su uso en la propagación de determinadas devociones (King 29; Díaz y Cabezas 185).

La imagen de esta estampita representa un espacio donde las figuras humanas se miran mutuamente, estableciendo un eje circular que empieza en los ojos de Jesús, descienden en el rostro del devoto hacia su corazón y sus manos en oración. Allí recibe nuevamente el eje la mano indicativa y acogedora de Jesús, siendo inmediatamente levantada la vista hacia el Sagrado Corazón, destacado por radiales luminosos y tomando el protagonismo de la escena. Este eje constituye el principal juego de miradas de la imagen, donde el observador busca ingresar.

Este grabado representa un nivel diferente de visualidad a la que observábamos previamente. En su iconografía establece niveles distintos de visión, ya que el Sagrado Corazón está de medio cuerpo sobre unas nubes. Esta indicación muestra una idea de compañía en la súplica, como si al momento de rezar se hiciera presente el corazón de Cristo, lo que se confirma en la exhortación que tiene en su cara posterior:

¡Cómo, alma que yo he llenado de beneficios, ibas á [sic] olvidarme y entregarte al mundo enemigo! Alma bautizada [...] Alma lavada con mi sangre, jtú querías revolcarte! Alma alimentada con mi carne, ¡tú te sentabas sin temor en el banquete de los impíos! Vuelve... la luz de mi Corazón te alumbra... su calor te abrasa... ¡Vuelve á mí, pobre pródigo que el demonio quería arrebatar á mi amor $!^{15}$

La continuidad que se crea entre la imagen y la palabra aumentan la eficacia de estos objetos, acentuando la retórica del retorno y del hijo pródigo. Por otro lado, la visión empírea retratada desdobla al observador dentro de la imagen: el uso de esta estampita debería producir aquella sensación de bienestar que se lee en las miradas de los interlocutores. El texto de su cara anterior reafirma la circularidad visual y narrativa de la composición proyectada al usuario: "La vuelta a Jesús. Vos habéis iluminado mi corazón, Dios Mío, él se entrega... y está con el vuestro". Toda la estampita conduce a la prédica sobre enmendar el camino, volver amorosamente (pastoralmente) a la devoción. El mensaje particular del Sagrado Corazón se erige en oposición a otras representaciones que enfatizan el sufrimiento, el dolor y el sacrificio de Cristo. La economía emocional de esta imagen apunta a la integración amorosa dentro de

14 El registro completo se puede revisar aquí: http://www.surdoc.cl/registro/3-41642 (Consultado 29 de junio de 2018). 15 La transcripción literal puede encontrarse en la ficha suRdoc de la estampita. Lo mismo aplica al resto de las transcripciones de oraciones e inscripciones de las estampitas que siguen. 
una comunidad, no al sufrimiento como experiencia aislada del sacrificio (tanto del devoto como el de Cristo).

Un elemento fundamental de este objeto es la textura realizada con troquelado, es decir, mediante recorte y relieve del papel que simula un encaje. Esta trama pareciera tener un carácter decorativo por sus entrelazados fitomórficos, sin embargo, continúa la imagen del grabado en el nimbo de Cristo y en el pequeño volumen a espaldas de la figura implorante, que simula un templete. Me parece relevante que la textura del objeto anula la sensación de espacio en la imagen, creando una contigüidad entre dos técnicas distintas que suprime el segundo plano y la posibilidad de una ilusión espacial. Nuevamente, la estampita carece de profundidad de campo, mostrándose como pura superficie. En palabras de Didi-Huberman, podríamos sostener que la imagen se vacía en su reflexividad, no entrega una dimensión otra, sino que se vuelve tautológica en la medida en que "elimina toda ilusión para imponer objetos llamados específicos, objetos que no exigían sino ser vistos por lo que eran” (28). Son imágenes que no necesariamente quieren ir más allá de lo que están presentando, sino que se mantienen en el "más acá".

La superficie se quiebra en una tercera estampita [Figura 3] ${ }^{16}$ que devuelve la mirada directamente al espectador, creando una interrupción del contacto, o quizás un síncope (Derrida 168). Este objeto muestra a San José (con sus lirios de atributo) sosteniendo al niño Jesús en sus brazos, quien tiene sobre su pecho al Sagrado Corazón en radiales brillantes. Bajo la representación del santo está escrito su nombre en francés, castellano, inglés y alemán, ${ }^{17}$ cada uno con tipografías diferentes, y está marcada por la imprenta. ${ }^{18}$ El punto determinante es que ambos personajes miran de frente al observador, punzando con la mirada, tocando en una intrusión al devoto. Esta mirada interrumpe lo que parece continuo.

Los elementos materiales de esta pieza replican los mismos mecanismos táctiles que he puntualizado para la imagen anterior, aunque en este caso el énfasis está en la mediación de un santo ante lo divino:

Imploramos tu piadosa asistencia, ¡oh San José! Tú que has tenido la gloria de llevar en tus brazos á Jesús, siéndo [sic] niño, preséntale nuestras humildes oraciones, para que no nos olvide en la hora de la muerte.

Esta estampita alude al observador para crear una sutura, y a diferencia de la imagen anterior, requiere crear una circularidad de miradas con el devoto. Mientras que en la anterior se crea una complicidad entre lo observado y el observador, entre el referente y el observador, esta imagen sustrae al orante del plano representado y lo separa de

\footnotetext{
16 Los detalles completos de esta estampita se pueden revisar en http://www.surdoc.cl/registro/3-41631 (Consultado 30 de junio de 2018).

17 Lo que evidencia su carácter de "objeto de exportación".

18 Firma como L. Turgis e Hijos, 60 Rue des Écoles, París.
} 


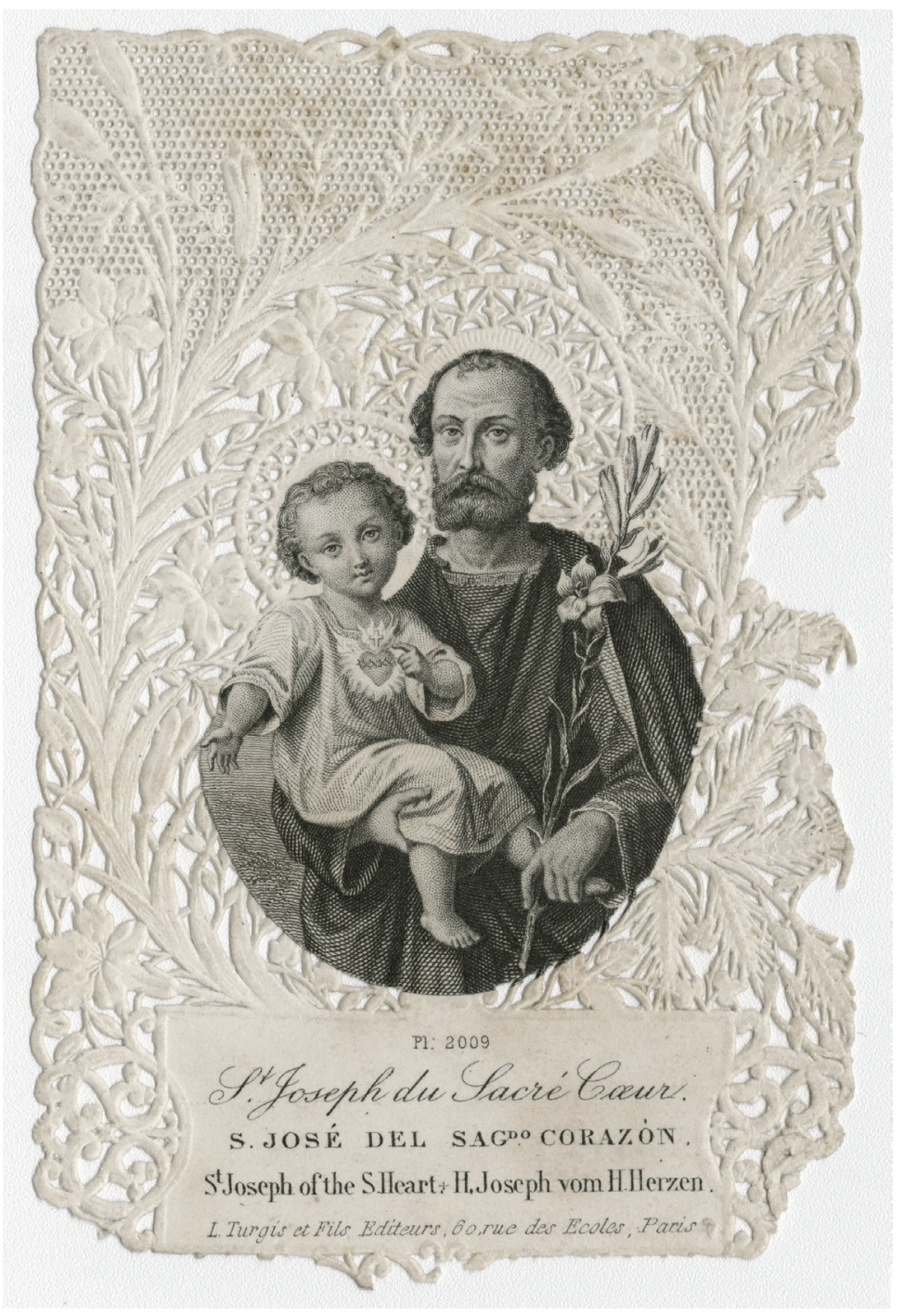

FIGURA 3

Estampa religiosa con San José del Sagrado Corazón.

Troquelado, grabado e impresión sobre papel, $6.1 \mathrm{~cm} \times 9.3 \mathrm{~cm}$, s. XIx. Colección Libros y Documentos,

Museo Histórico Nacional. 
ese espacio sagrado. Esa escisión, ${ }^{19}$ fundante de lo sagrado en un sentido institucional, solo se sutura con la oración, la que enfatiza la dicha del santo representado. La mirada separa y acoge al mismo tiempo, distancia y atrae hacia sí.

Otro componente clave es el gesto que hace el niño con sus manos. Mientras con una apunta a su corazón, con la otra se dirige fuera del plano, abriendo ambos brazos en una seña de hospitalidad. Esta forma de representar el sagrado corazón condensa la metáfora del corazón como amor divino hacia un símbolo de sacrificio y salvación, por ello la oración que lo acompaña destaca la redención a la hora de la muerte (Morgan, The Embodied Eye 117-127). La estampita actúa como mediación al mismo tiempo que hace más denso el significado que expresa.

Si bien los objetos revisados remiten a formas corporales de la percepción, existen otras figuras que apelan a la corporalidad de Cristo. Distanciada de las representaciones más elocuentes de una corporalidad sufriente, una cuarta estampa [Figura $4]^{20}$ presenta una escena de oración frente a la hostia consagrada, es decir, frente al cuerpo transustanciado de Cristo.

En la iconografía se muestra a un/una joven orando frente a una custodia, cuya mirada se dirige a la presencia que comparece ante la oración: nuevamente Cristo, quien se deja entrever en una humareda célica. Sus ojos están semicerrados, pero sus manos apuntan a su pecho, de donde sale un rayo luminoso que perfora toda la composición hasta el pecho del devoto. La imagen está coronada con la frase en francés "Mon Coeur Est amour et l' amour se donne" (mi corazón es amor y el amor se da), la que refuerza el sentido sobrecargado del corazón como símbolo del amor de Cristo.

En esta imagen se produce la contradicción de tocar aquello que es intocable: no se puede tocar la visión de Cristo, ni su cuerpo expuesto cual reliquia en la custodia, no obstante, la fuerza de su presencia crea una afinidad por contigüidad, una proximidad cómplice que se consuma en un "intuicionismo háptico" que viene a "satisfacer el movimiento corporal de un deseo, como deseo de presencia” (Derrida 180).

Bajo la imagen y en el mismo idioma se encuentra otra leyenda alusiva al mismo tema, que podría traducirse como: "Está a los pies del tabernáculo donde los ojos se sitúan. Estos rayos de la hostia que nos enseña Dios y los misterios de su justicia que son también los misterios de la infinita bondad". Es interesante destacar que la escritura incita al lector a bajar la mirada ante la visión de Cristo y a observar los "misterios de su bondad" desde una apreciación en recogimiento.

Esta iconografía en particular remite a elementos institucionales: la escena ocurre en un altar, por lo tanto, en el interior de una iglesia (como si transportar

19 Respecto de la definición de lo religioso, Giorgio Agamben ha sostenido que toda separación es una huella religiosa, y que lo religioso se caracteriza precisamente por la independencia de las esferas divina y humana. Creo que esta forma de entender lo sagrado se aplica a las formas tradicionales, donde el acceso a lo sagrado es necesariamente mediado por una institución, ya que se vivencia lo sagrado como una radicalidad otra. En cambio, estos objetos y estas devociones se inscriben en un movimiento de la sacralidad que es practicada y activada por los devotos. Ver Agamben; Gutiérrez.

20 Véase el registro completo en: http://www.surdoc.cl/registro/3-41607 (Consultado 30 de septiembre de 2018). 


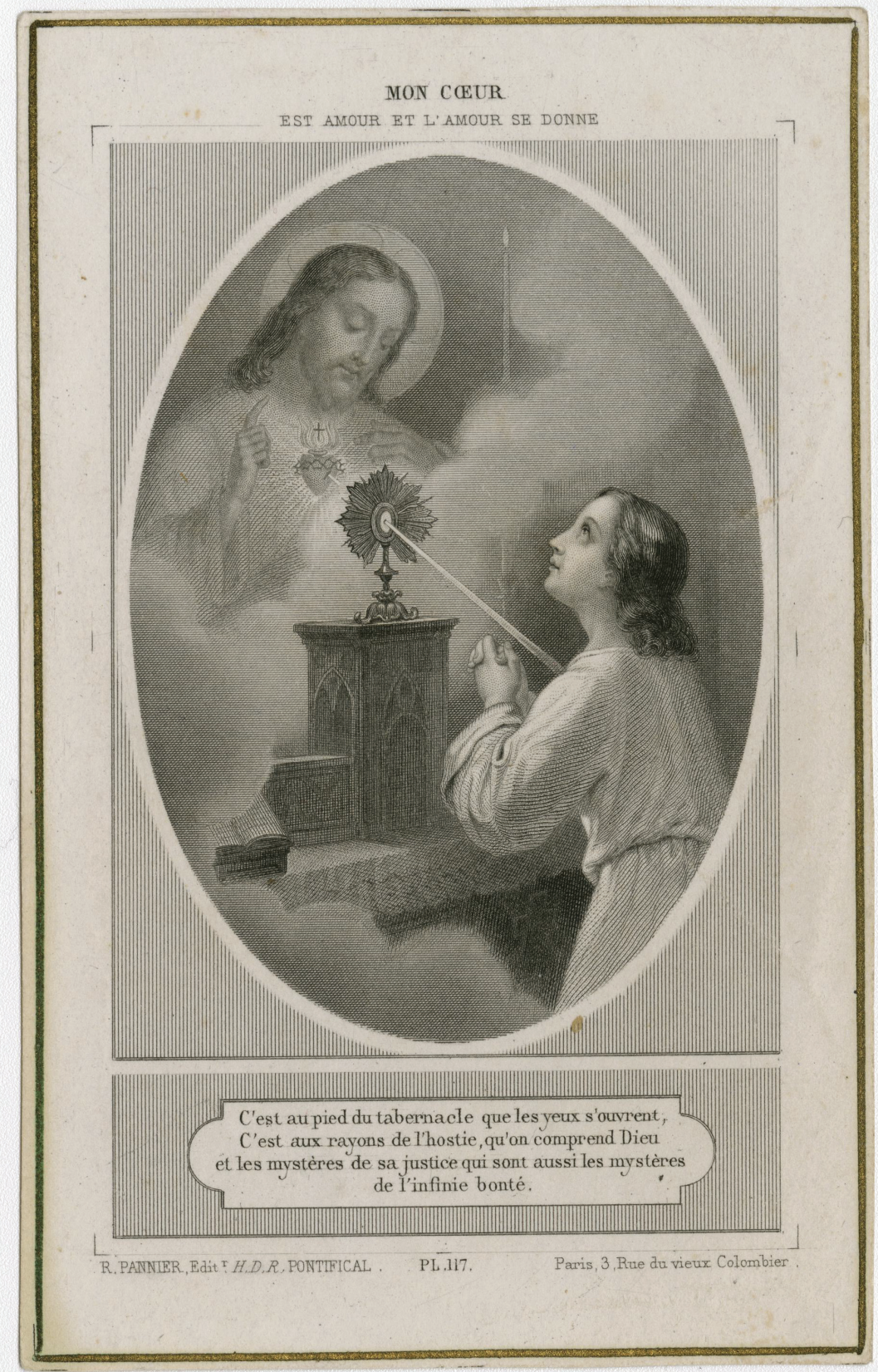

\section{FIGURA 4}

Oración al Sagrado Corazón de Jesús. Litografía,

impresión y manuscrito sobre papel, $7.3 \mathrm{~cm} \times 11.7 \mathrm{~cm}$,

ca. 1900. Colección Libros y Documentos,

Museo Histórico Nacional. 
la estampita fuera una manera de entrar en un templo). A su vez, la oración que se adjunta en el reverso a la estampita enfatiza un ruego por el "feliz estado de la Santa Iglesia y prelados de ella, por la intención del Sumo Pontífice, la exaltación de la santa fe católica, paz y concordia entre los príncipes cristianos”. En síntesis, el cuerpo de Cristo representado tanto en la hostia como la aparición hace las veces de cuerpo eclesial, lo que se corrobora en la representación del dogma de la transustanciación en la hostia consagrada.

Cada una de las estampitas revisadas implica esquemas corporales distintos. Desde el llamado a tocar, a recorrerlas, hasta la separación que conduce a observar el lugar institucional donde se instalan. Ante ellas se realizan distintos actos, posturas, gestos de oración. Aunque todas tienen en común la cercanía, todas se pueden tomar entre las manos. Estas imágenes podrían pensarse como membranas de sacralidad, como objetos delicados aunque complejos en su constitución, que tienen la conciencia de ser observados y observadores a la vez.

\section{Al alcance de las manos}

En este ensayo me he concentrado en cómo determinado grupo de imágenes afecta al observador y se inscribe en un registro de cultura visual religiosa particular. Con estos recorridos he intentado volver el centro de atención a los efectos del cuerpo y las formas de tocar. Las imágenes analizadas mantienen una leve congruencia en sus funciones e iconografías, lo que permite observarlas en conjunto. Habría que investigar cómo se transforman otras devociones que adoptan mecanismos similares para simpatizar con el observador, para crear esas dimensiones de acogida, compañía y cercanía, puesto que estas estampitas son parte de una cultura visual religiosa católica que históricamente se empieza a instalar entre finales de siglo xix y principios del xx.

Todas estas imágenes comportan un elemento común en sus formas de representar: nunca pretender establecer un "espacio otro", o una ilusión de otra realidad. No buscan "engañar al ojo" creando la ilusión de otro espacio, por el contrario, afirman su inmediatez. Se agotan en su presencia, se agotan en el contacto, se expresan en el contacto, donde el diálogo tiene lugar en las manos. Según he afirmado, estas son características que hacen pensar en las formas de visualidad háptica, donde destaca la superficialidad, la proximidad, la contigüidad entre el observador y lo observado, donde la imagen captura a quien la observa y la toca.

He tratado de esbozar una propuesta de exploración a estas imágenes, las que por su naturaleza y popularidad me parecen complejas y seductoras, imágenes profundamente persuasivas y efectivas en su difusión. Las estampitas plantean también problemas en torno a las posibilidades de la sacralización, ya que pueden crear una relación de intimidad no mediada (o no ritualizada) con lo sagrado mismo: funcionan como reliquias modernas, cargadas de sacralidad y potencia absoluta de una forma 
de lo sagrado que no está alejada de la experiencia, no está en una esfera ontológica diferente, sino que está al alcance de la mano. En ese sentido mantienen una dualidad: son imágenes que reproducen formas ortodoxas de la iglesia (dogmas particulares, historias, oraciones oficiales), mientras que promueven una devoción privada e independiente de las organizaciones eclesiales.

En resumidas cuentas, se trata de imágenes sensuales, de imágenes de profunda contaminación y peligrosidad de lo sagrado. Insisto: no mantienen una promesa por algo "por venir", sino que se quedan en este espacio, en el observador, en el orante. Imágenes tautológicas.

\section{Referencias}

Agamben, Giorgio. Profanaciones. Buenos Aires, Adriana Hidalgo Editora, 2009.

Báez, Rolando, Lily Jiménez, Hugo Rueda. Formas para recordar. Objetos e imágenes de devoción. Santiago, Museo Histórico Nacional, 2016.

Castillo, Alejandra. Imagen, cuerpo. Buenos Aires, Palinodia, La Cebra, 2015.

De la Torre, Renée y Eloísa Martín. "Estudios Sobre Religión en América Latina". Annual Review of Sociology, vol. 42, 2016, pp. 1-21.

Deleuze, Gilles. Francis Bacon. La lógica de la sensación. Madrid, Arena Libros, 2002.

Derrida, Jacques. El tocar, Jean-Luc Nancy. Buenos Aires, Amorrortu, 2011.

Díaz, Claudio, Catalina Aravena y Juan Cabezas. "La escultura sacra industrial: los talleres artísticos de Saint Sulpice y Fran Mayer de Munich”. vv. AA. Escultura Sacra Patrimonial en Santiago de Chile. Siglos XVI al Xx. Santiago, Ograma, 2016, pp. 183-237.

Didi-Huberman, Georges. Lo que vemos, lo que nos mira. Buenos Aires, Manantial, 2010.

Droogan, Julian. Religion, Material Culture, and Archaeology. Nueva York, Continuum, 2012.

Elkins, James. Pictures and Tears. A History of People who have Cried in front of Images. Nueva York y Londres, Routledge, 2004.

Freedberg, David. El poder de las imágenes. Estudios sobre la historia y teoría de la respuesta. Madrid, Cátedra, 2009.

Gutiérrez, Daniel (comp.). Religiosidades y creencias contemporáneas: diversidades de lo simbólico en el mundo actual. México, El Colegio Mexiquense, 2010.

Jacobo, María de Lourdes. "Religiosidad instituyente y corporalidad en la iconografía sagrada de los exvotos de San Juan de los Lagos”. Revista Cultura y Religión, vol. 8, n. $^{\circ} 2,2014$, pp. 7-32.

King, E. Frances. Material Religion and Popular Culture. Nueva York, Routledge, 2010. Martín, Eloísa. “Aportes al concepto de 'religiosidad popular': una revisión de la bibliografía argentina”. Ciencias Sociales y religión en América Latina. Perspectivas en debate. Buenos Aires, Biblos, 2007, pp. 61-86. 
McDannell, Colleen. Material Christianity. Religion and Popular Culture in America. New Haven y Londres, Yale University Press, 1995.

Meyer, Birgit, David Morgan, Crispin Paine y S. Brent Plate. “The Origin and Mission of Material Religion". Religion, vol. 40, n. ${ }^{\circ} 3,2010$, pp. 207-11.

Mitchell, W. J. T. Iconology: Image, Text, Ideology. Chicago y Londres, The University of Chicago Press, 1986.

Morgan, David (ed.). Religion and Material Culture: The Matter of Belief. Londres, Routledge, 2010.

Morgan, David. The Sacred Gaze: Religious Visual Culture in Theory and Practice. California, The University of California Press, 2005.

- - . The Sacred Heart of Jesus. The Visual Evolution of a Devotion. Ámsterdam, Amsterdam University Press, 2008.

- - The Embodied Eye. Religious Visual Culture and the Social Life of Feeling. California, The University of California Press, 2012.

Nancy, Jean Luc. Noli me tangere. Ensayo sobre el levantamiento del cuerpo. Madrid, Trotta Mínima, 2006.

Nooter Roberts, Mary. "Tactility and Transcendence. Epistemologies of Touch in African Arts and Spiritualities". Religion and Material Culture: The Matter of Belief, Ed. David Morgan. Londres, Routledge, 2010, pp. 77-96.

Rueda, Hugo. "De forma y sentido. Reflexiones en torno a la patrimonialización de recuerdos, objetos y prácticas religiosas”. Formas para recordar. Objetos e imágenes de devoción. Santiago, Museo Histórico Nacional, 2016, 8-21.

Enviado: 8 de agosto de 2018 Aceptado: 27 de diciembre de 2019 